\title{
Building up resources and knowledge to unravel transcriptomics dynamics underlying Eucalyptus globulus xylogenesis
}

\author{
Jorge AP Paiva ${ }^{1 *}$, José Carlos Rodrigues ${ }^{2}$, Pedro Fevereiro ${ }^{3}$, Lucinda Neves $^{4}$, Clara Araújo ${ }^{4}$, Cristina Marques ${ }^{5}$, \\ Ana Teresa Freitas ${ }^{6}$, Hélène Bergès ${ }^{7}$, Jacqueline Grima-Pettenati ${ }^{8}$ \\ From IUFRO Tree Biotechnology Conference 2011: From Genomes to Integration and Delivery \\ Arraial d Ajuda, Bahia, Brazil. 26 June - 2 July 2011
}

The economic importance of some Eucalyptus species, including interspecific hybrids, has been extended from the traditional interest of pulp and paper production to the emergent areas of bio-fuels and bio-materials. New genomic resources and high throughput technologies have provided the Eucalyptus research international community with the opportunities to identify genomic regions of interest in order to comprehensively dissect, catalogue and characterize genes involved in the determination of wood formation and quality. Similar strategies can be now applied to identify key regulator genes and better understand the cellular mechanisms by which they modulate the complex molecular events occurring in xylogenesis.

The Geneglob ${ }^{w q}$ project (2006-2010) produced and used a set of genomic tools which, associated with Next Generation Sequencing (NGS) technologies, allowed us to expand the knowledge of the Eucalyptus genome by focusing on regions potentially involved in the determination of wood properties, namely pulp yield and lignin content. We first start to characterize two E. grandis BAC libraries [1] constructed by the Arizona Genome Institute (with DNA from the clone Brasuz S1 whose genome was sequenced recently by the DOE [http:// www.jgi.doe.gov/sequencing/why/99176.html], and two E. globulus BAC libraries made available by RAIZ [http://www.raiz-iifp.pt/]. We than used 3D-pools of $\mathrm{BAC}$ libraries and BAC macroarrays to characterize

\footnotetext{
* Correspondence: jorge@itqb.unl.pt

'Instituto de Investigação Científica e Tropical (IICT/MCTES) Palácio Burnay -

Rua da Junqueira, 30, 1349-007 Lisboa, Portugal Instituto de Biologia Experimental e Tecnológica (IBET) Av. da República, Quinta do Marquês, 2781-901 Oeiras, Portugal

Full list of author information is available at the end of the article
}

genomic environment of several lignin and lignin-regulator genes (e.g.EguCCR, EguCAD2 and EguRAC1) both in E. grandis and E. globulus. The shotgun sequencing of selected BAC clones containing those genes generated a high amount of sequencing data that made it possible to map the E. globulus BAC sequenced clones against the $E$. grandis genome (8X coverage). These comparative analyses showed extended microlinearity between both genomes, at least in the studied regions. Additionally, we have sequenced and annotated the chloroplast genome of E. grandis (GeneBank Accession NC_014570) [1].

A global approach to unravel E. globulus transcriptome dynamics has also been included and structured in the Geneglob ${ }^{w q}$ project, aiming at the identification of genomic hotspots of transcription activity. Various $E$. globulus xylogenesis "models" have been considered comprising several paired, contrasting wood forming tissues (provided by RAIZ): i) xylem samples collected along the year (season variation); ii) juvenile and adult individuals of a single genotype; iii) contrasting genotypes for pulp yield. Samples from these tissues were used for transcriptome sequencing using IlluminaHi-Seq technology (mRNA-SEQ). The same E. globulus genotype used for both E. globulus BAC libraries (a parent tree used in controlled crosses by RAIZ) has been resequenced (pair-end 100bp), and provided the first draft of an E. globulus genome. This resequencing data was mapped against the $E$. grandis Brasuz S1 reference genome. Transcriptomic data were also blatted against the gene models annotated in E. grandis genome, to evaluate in silico the expression of each gene.

More recently, the microEGo project (2010-2012) started the identification and characterization of Eucalyptus 
globulus microRNAs and their target genes, involved in the regulation of wood formation. The E. globulus season variation xylogenesis "model" was used considered for this project as well as an E. globulus reaction wood "model". The latter comprises reaction wood tissues (tension / opposite wood) formed in bent trees at different kinetic times of gravitropic stimulation and control wood (nonbent trees). Small RNA libraries have been generated from those tissues and sequenced using IlluminaHi-Seq technology (Small RNAs-SEQ). The sequencing data from both microEGo and Geneglob ${ }^{w q}$ projects together with a genome wide bioinformatics analysis of $E$. grandis reference genome and E. globulus genome are being used for identification of miRNA gene and putative their putative target-genes.

These projects will hopefully constitute an important piece in the assemblage of whole new categories of knowledge and genomic resources for the Eucalyptus community, providing insights into the nature of the molecular machinery involved in wood formation and most importantly in the identification of key players determining the variability of wood characteristics and its end-uses.

\footnotetext{
Acknowledgments

This work has been partially supported by Fundação para a Ciência e Tecnologia (Portugal): http://PTDC/AGR-GPL/098179/2008, "microEGO - Did you ask for something small? The microRNAs power in a Eucalyptus tension world! (https://sites.google.com/site/microegopublic/); PTDC/AGR-GPL/66564/ 2006, "GenEglob"w - Scanning for candidate genes underlying a pulp yield QTL in Eucalyptus globulus" (http://geneglob.inesc-id.pt/). We would like to aknowledge ALTRI FLORESTAL SA (Portugal) and RAIZ (Portugal) for providing the plant material used in these studies.

The authors would like to thank the valuable contribution of actual and former members of the involved groups and institutions: Susana Araújo ${ }^{1,2}$, Teresa Quilhó1, Nuno Borralho', Ricardo Barrela', Douglas Freitas', Victor Carocha ${ }^{1,2}$, Clara Graça ${ }^{1}$, Joana Amado ${ }^{1}$, Filipa Cardeano ${ }^{1}$, Paulo Fonseca ${ }^{5}$, Nuno Mendo ${ }^{5}$, Elisa Prat ${ }^{6}$, Sonia Vautrin ${ }^{6}$, Joelle Fourment ${ }^{6}$, Nathalie Ladouce, ${ }^{7}$ Hélène San-Clemente ${ }^{7}$, Hua Wang ${ }^{7}$ and Andreia Fonseca (IMM-UL, Lisboa).
}

\section{Author details}

'Instituto de Investigação Científica e Tropical (IICT/MCTES) Palácio Burnay Rua da Junqueira, 30, 1349-007 Lisboa, Portugal Instituto de Biologia Experimental e Tecnológica (IBET) Av. da República, Quinta do Marquês, 2781-901 Oeiras, Portugal. ${ }^{2}$ Instituto de Investigação Científica e Tropical (IICT/MCTES) Palácio Burnay - Rua da Junqueira, 30, 1349-007 Lisboa, Portugal. ${ }^{3}$ Instituto de Biologia Experimental e Tecnológica (IBET) Av. da República, Quinta do Marquês, 2781-901 Oeiras, Portugal. ${ }^{4}$ ALTRI FLORESTAL SA, Quinta do Furadouro 2250-582 Olho Marinho, Portugal. ${ }^{5}$ RAIZ, Herdade de Espirra, 2985-270 Pegões, Portugal. ${ }^{6}$ INESC-ID - Instituto de Engenharia de Sistemas e Computadores, R. Alves Redol 9, 1000 Lisbon, Portugal. ${ }^{7}$ INRACNRGV - chemin de Borde Rouge 31326 Castanet-Tolosan, France. ${ }^{8}$ UMR CNRS/Université Toulouse III 5546, Pôle de Biotechnologies Végétales, 24 chemin de Borde Rouge, BP42617 Auzeville, 31326 Castanet, Tolosan, France.

Published: 13 September 2011

\section{Reference}

1. Paiva JAP, Prat $E$, Vautrin $S$, Santos MD, San-Clemente $H$, Brommonschenkel S, Fonseca PG, Grattapaglia D, Song X, Ammiraju JSS, Kudrna D, Wing RA, Freitas AT, Berges H, Grima-Pettenati J: Advancing
Eucalyptus genomics: identification and sequencing of lignin biosynthesis genes from deep-coverage BAC libraries. BMC Genomics 2011, 12:137, doi:10.1186/1471-2164-12-137.

doi:10.1186/1753-6561-5-S7-052

Cite this article as: Paiva et al:: Building up resources and knowledge to unravel transcriptomics dynamics underlying Eucalyptus globulus xylogenesis. BMC Proceedings 2011 5(Suppl 7):O52.

\section{Submit your next manuscript to BioMed Central and take full advantage of:}

- Convenient online submission

- Thorough peer review

- No space constraints or color figure charges

- Immediate publication on acceptance

- Inclusion in PubMed, CAS, Scopus and Google Scholar

- Research which is freely available for redistribution
C Biomed Central 